\title{
Nusantarazation Environmental Paradigm: Sustaining Biodiversity and Culture in Nusantara Malay Archipelago with Local Ecological Knowledge (LEK)
}

\author{
Sazlina Salleh $^{1 *}$, Mahadi Mohammad ${ }^{2}$, Mohammad Reevany Bustami ${ }^{1}$ \\ ${ }^{1}$ Centre for Policy Research \& International Studies, Universiti Sains Malaysia, 11800 Pulau Pinang, \\ Malaysia \\ ${ }^{2}$ School of Biological Studies, Universiti Sains Malaysia, 11800 Pulau Pinang, Malaysia
}

\begin{abstract}
Since Nusantara Malay Archipelago is a maritime community, its indigenous knowledge and local wisdom is largely connected to sea life and water. Nevertheless, there are also mountains, valleys, forests and flatlands; hence, local knowledge is also connected to these landscapes and spaces. This article submits the environmental paradigm of Nusantarazation and its interconnectedness with local ecological knowledge (LEK) as well as reports on findings in the form of case exemplars in the field related to these constructs. The authors argue that Nusantarazation is an epistemological paradigm which is able to decolonize environment knowledge and provide an integrative framework for LEK, sustainable practices and technological know-how. The spatial scope covers mainly areas in Malaysia and Indonesia as these are part of Nusantara. Among the key findings are that LEK tend to be accompanied with seemingly unscientific or mythical narratives but are translated into practices that promote sustainability either in the land or waters. This article also capture various local constructs and beliefs that capture the underlying value systems which are integral to conservation and ecological balance. Nevertheless, the Nusantarazation environmental paradigm encounters challenges from colonial legacies of power modern practices and industrial complex that threaten to harm the environment and humanity.
\end{abstract}

Keywords: Nusantara Malay Archipelago, Local Ecological Knowledge (LEK), Nusantarazation, Indigenous / Local wisdom

*Corresponding Author:

E-mail: sazlina@usm.my (Sazlina Salleh)

Centre for Policy Research \& International Studies, Universiti Sains Malaysia, 11800 Pulau Pinang, Malaysia

\section{INTRODUCTION}

Local Ecological Knowledge (LEK) and indigenous knowledge is a complex understanding of the environment, livelihood activities, legend and social practices. Berkes et al. (2010) define LEK as a cumulative body of knowledge, beliefs and traditions handed down through generations. LEK tends to be communally owned and in songs, folklores, stories, proverbs, cultural values, beliefs, community/local custom laws and livelihood practices.
The global loss of biodiversity is a severe environmental problem, and it exacerbates climate change and global warming. LEK and indigenous knowledge have been acknowledged as a methodological tool to assist biodiversity and conservation management. Hence, the Intergovernmental Platform on Biodiversity and Ecosystem Services (IPBES) includes the following commitment as one of its operating principles (Karki et al.):
Journal Homepage:

http://ejournal.undwi.ac.id/index.php/jsds
Copyright (C) 2021 Dwijendra University. All right reserved. 
Journal of Sustainable Development Science

Vol. 3, No. 2, December 2021, pp. 77-83

e-ISSN: 2715-9140|p-ISSN: 2722-919X

"Recognize and respect the
contribution of indigenous and local
knowledge to the conservation and
sustainable use of biodiversity and
ecosystems."

UNEP/IPBES.MI/2/9, Appendix 1, para. $2(\mathrm{~d})$

\section{METHODS}

It has been acknowledged that LEKs could contribute to climate action under Sustainable Developments (SGD) 13 (Climate Change), 14 (Life on Land) and 15 (Life below Water) by predicting, responding and adapting to its impact. Hence, obtaining data directly from the resource users is considered an ideal approach in monitoring and managing the ecosystem. Studies have shown the importance of LEK in planning and managing conservation areas (e.g: Johannes et al. 2008). The application of fostering harmony with nature has enabled the local and indigenous communities to cope and adapt to climate variability for thousands of years. Through knowledge transmitted orally for generations, the local communities can predict climate variability using local environmental and astronomical indicators.

\section{RESULT AND DISCUSSION}

Conservation of the environment through Nusantarazation Paradigm as a Decolonizing Episteme of Local Ecological Knowledge and as Synthesis with Scientific/Technological Know-how

Nusantarazation as a decolonization social-environmental episteme, thus, is the exploration and understanding of the LEK in the context of Nusantara as a social-cultural and environmental space, and the integration of LEK with scientific knowledge, social innovation or local know-how and technological applications. Nusantara, as a geographical space, covers the whole of Malay Archipelago (both oceans and islands) and a substantial part of Indochina, a region that overlaps with and predates Southeast Asia.

As a research agenda and analytical framework, Nusantarazation of knowledge related to natural environment thus captures the interconnection of several dimensional components: (1) context, both environmental and social (2) story/narrative, (3) values/principles, (4) practice, (5) the connection to sustainability and conservation. The analysis of LEK from the Nusantarazation environmental paradigm, thus, may consist of one or a combination of these components.

\section{Nusantarazation Environmental Paradigm and LEK}

Applying this Nusantarazation environmental paradigm to the concept of "Keramat" or sacredness, one of the most common LEK in the region, reveals a multilayered understanding. The context is both environmental and social. Keramat or tempat keramat (sacred space) can be associated to a large environmental context like a mountain, land, forest, island and sea or some natural entity that is more specific like a cave, river, or even a tree. Therefore, the social contexts are the communities or people who live in the surrounding areas or visitors who have activities and who may enter or may be in close proximity to these sacred spaces or entities. A prime example is pohon beringin or its scientific name Ficus benjamina or more commonly known as banyan tree. It is a tree which may grow as tall as 30 meters and may cast a wide canopy shade. It is actually 
Journal of Sustainable Development Science

Vol. 3, No. 2, December 2021, pp. 77-83

e-ISSN: 2715-9140|p-ISSN: 2722-919X

an epiphyte. It is a fig that grows on another tree. It can grow as/on a single tree or in pairs as found at Alun-alun Jogjokarta. It is also in the coat of arms in Indonesia, symbolizing the third tenet of the national philosophy of Pancasila as a unifying image.

The story or narrative conveyed to the society is that it is considered sacred for the following reasons. It is a place for deities or saints or ancestors (and in some cases, even supposedly evil spirits); hence, chopping down the tree leads to a curse or misfortune. For couples who walk in between a pair of beringin trees, their relationship can last a lifetime. The practice of worshipping or preservation includes at times offerings to or at the beringin tree. As it grows tall and wide, often an important symbolic value attached to the tree is leadership; consequently, many local and national figures plant them in the compounds of their homes or even offices. As an extended myth, the tree is narrated within the story of Sunan Kalijaga, one of the nine muslim saints (Wali Songo) in Java. The martial arts of Ajian Waringin Sungsang (which literally means the upside down beringin tree) is said to have the ability to subdue all black arts or evil sorceries. It is based on the philosophy that when the beringin tree is upside down, the massive roots can be seen, and the massiveness of the roots also symbolizes the sources of strength, happiness and greatness and the origins of life itself. The projection of power from beringin sungsang is so supreme that is able to absorb and relinquish dark energies. All these stories and so-called mythical narratives, values and beliefs preserve the existence of beringin trees. Indeed, vis-à-vis sustainability, this indirectly is conservation. It is also found that where a beringin tree grows, there is also underground water source. The extensiveness of the roots helps to mitigate floods and prevent soil erosion. It is also known for its herbal properties, including as part of treatment for flu, cough and internal inflammation.

Biodiversity of biological diversity refers to the biological variety and variability of life on Earth. The overwhelming evidence reported by the intergovernmental SciencePolicy Platform on Biodiversity and Ecosystem Services (IPBES) noted that "Nature is declining globally at rates unprecedented in human history - and the rate of species extinctions is accelerating" but more than $30 \%$ of the Earth is already conserved due to the local wisdom and practices of the indigenous and local communities. The indigenous and local communities have a mutual bond with nature, rather than viewing nature as existing to serve humans. As a rule, they respect the forest as it supports their livelihood. To them, the forest is their school, food provider, and hospital. For these reasons, destroying the forest is like destroying their collective wisdom, their livelihood and their source of healing. The local indigenous community in Sarawak (Lun Bawang, Sa'ban and Penan), Malaysian Borneo, recognize the forests as a buffer to protect paddy fields and provide alternative resources. Consequently, no human activities (except hunting) are permitted and apply the concept of "kill only enough for food" and "take only what you need" in their daily ritual; thus, making them the ideal environmental stewards (Hosen et al. 2020).

The knowledge and intelligence of the local community can be used in helping conservation efforts, and their deep understanding and observation could provide
Journal Homepage:

http://ejournal.undwi.ac.id/index.php/jsds
Copyright (C) 2021 Dwijendra University. All right reserved. 
first-hand information on environmental change. Obtaining scientific information on ecological biodiversity would require field biologists to spend months collecting data and would be costly. Therefore, using local knowledge to collect, corroborate or complement data is a practical substitute, especially in areas where access is limited, and the wide distribution of species logistically prohibits thorough sampling (Rajamani 2013; Meilana and Fang 2020). Using the Wisdom and Crowds approach (WoC) Meilana and Fang (2020), have obtained information on horseshoe crab status in the Indonesian coastal, which is valuable for conservation management. The authors identified districts where local communities consume horseshoe eggs due to shared beliefs (health benefits). In contrast, some in district horseshoe crabs are considered pests that only have adverse economic effects. Such information is essential and should be used in implementing conservation and awareness programs.

Nusantarazation of knowledge also leads to better data. Local fishers have firsthand experience and understanding of the environment they develop, including the direct assessment of local marine stocks and how they change over time, which most marine biologists rarely have. Importantly local communities can provide historical data, especially in remote and poorly studied locations (Drew 2005). Hence, employing LEK and working with communities helps gather critical data for better management. Md Saleh (2014), for example, has incorporated data gathered from the local communities in Terengganu, Malaysia to understand the behaviour of unicorn leatherjacket filefish better, Aluterus monocerus (Lennaeus, 1758) or locally known as "ikan barat-barat" or "ikan ayamayam". Information on abundance, seasonal distribution and catch trends provided by the local fishers provide a better understanding of management priorities for the Department of Fisheries Malaysia. As the local fishers spent much time observing and understanding the fish behaviour, they were able to design a lift net (fishing gear) specifically to catch the unicorn leatherjacket filefish with almost $100 \%$ accuracy, thus avoiding unnecessary catch. The governing local Nusantara value is to take the necessary but leave the rest unharmed or at least to reduce harm as much as possible. These nets are known as "tangguk darat" or "sauk barat" locally. This is an example of local practice of Nusantara born out of local creative ingenuity. These comprehensive or longitudinal-based LEKS are valuable as designing such equipment and administering the data collection requires extensive research. Equally if not a more important point is that it is part of sustainable fishing.

In the conservation initiative of Pulau Payar Marine Park, Malaysia, the local marine park authorities have been working closely with the local communities and fishers to help mitigate reef degradation. The invasive snowflake coral, Carijoa riise $i$ has negatively impacted the coral communities in Pulau Payar, and this species overgrows and often adversely affects the ecosystem on a large scale. With a vast knowledge of the coral reef in Pulau Payar, the local community has helped authorities identify and remove these invasive organisms. Engagement with the local fishers confirms the presence of the invasive species and provides information on the status of the reef.
Journal Homepage:

http://ejournal.undwi.ac.id/index.php/jsds
Copyright (C) 2021 Dwijendra University. All right reserved. 
Apart from providing valuable information to the authorities, the local communities are appreciative of biodiversity. Similarly, the local communities have provided information on the significant contribution to reef degradation (Elliott et al. 2001) in the Marine Protected Area (MPA) of Wakatobi National Park, Sulawesi, Indonesia. Monitoring the status of the resource and changes in the ecosystem is a crucial practice among many of these local Nusantara communities to sustain their livelihood. For example, the practice of sensing, observing and understanding the winds and water movement would enable them to know where to catch and what to catch.

The combination of LEK, rituals and beliefs synergizes into tools used to manage deforestation and open burning. This is a classic case of Nusantarazation paradigm. According to Sintian (2013), local communities of Kadazandusun in Sabah, Malaysia (in the northern Nusantara island of Borneo) have been observing the LEK, which includes rituals and beliefs following the concept of "Environment is a precious creation of God and it is our accountability to manage the natural resources with a goodcare". The belief and superstitions include practices related to land clearing for agricultural activities. The taboos and rituals in choosing the land and during land clearing have assisted in environmental conservation locally. Understanding the signs and signals from the environment is essential to avoid unwanted incidents. For example, the beliefs like gawoi dream can be used to determine if the land is suitable for farming thus, this will assist unwanted land clearing (Sintan et al. 2019). The close relationship between LEKs and traditional beliefs has proven that many local and indigenous communities have been practicing sustainable agriculture for generations.

The Nusantarazation environmental paradigm also sheds light to the integration and deployment of LEK into practical application vis-à-vis agriculture. The agricultural contextualization of LEK has been observed for generations in many societies. By understanding how nature works through years of observation, local farmers of Nusantara have been using organic waste as fertilizer and herbs as incest repellent to safeguard their crops. For example, local farmers in Malaysia have been using lemon juice and vinegar to stabilize soil $\mathrm{pH}$ and antimicrobial. Heryanto et al. (2018) documented the traditional practices of farmer communities in Mekarjaya village, West Jaya. As the foundation of local wisdom is living in harmony with mother nature, traditional practices during paddy cultivation in Merjarjaya includes phrases of social values such as 'responsible and respect'; hence practices of pest management do not kill or eliminate pest during the paddy growth period but drive them away. This requires indepth knowledge on the biology and behavior of the pest (Black bug / Scotinophara coarctata or locally known as lembing batu. The concept 'responsible and respect' has become their principle as they acknowledge that all organisms are part of the complex food webs. This is an integral part of their belief system about ecology in Nusantara. This local knowledge in agricultural activities have helped in sustaining the environment and conserving biodiversity.

However, due to the demand in crop production, the chemical pesticide was introduced, eliminating the responsible and
Journal Homepage:

http://ejournal.undwi.ac.id/index.php/jsds
Copyright (C) 2021 Dwijendra University. All right reserved. 
Journal of Sustainable Development Science

Vol. 3, No. 2, December 2021, pp. 77-83

e-ISSN: 2715-9140|p-ISSN: 2722-919X

respect' practices. In addition, the usage of organic fertilizer was widely used before the introduction of synthetic fertilizer to increase crop production. With the powerful legacy of colonial industrial complex, the replacement of traditional practices by modern technology is arguably unavoidable under the capitalistled globalization regime, as it is cheaper, often designed to require less manual labor and widely advertised and distributed as well as legally permitted. This is a case where science without wisdom and responsibility can be employed to destroy the environment to benefit the few, at least in the short term.

\section{CONCLUSION}

In the context of Nusantara Malay Archipelago, LEK is not only limited to environment, conservation, and agriculture, but it has an immense value in education and in the field of medicine. The local and indigenous community of Nusantara have their own traditional way of conservation of the natural ecosystems. As an epistemological paradigm, Nusantarazation decolonizes development itself by integrating and synergizing local wisdom and scientific knowledge in the context of everyday as well as the long-term sustainability. Indeed, the practices of LEKs when analyzed and contextualized with this paradigm has the high potential to revive sustainable development of biodiversity as well as reempower responsible usage of resources which ultimately restores balance for the environment and communities living in it. Therefore, to Nusantarize is to decolonize the communities of Nusantara Malay Archipelago from the institutional and ideological shackles of the colonizers and liberate and integrate humanity with the natural environment.

\section{REFERENCES}

Berkes F, Colding J, Folke C (2010) Rediscovery of Traditional Ecological Knowledge as Adaptive Management Published by: Ecological Society of America REDISCOVERY OF TRADITIONAL ECOLOGICAL KNOWLEDGE. Ecol Appl 10:1251-1262

Drew JA (2005) Use of traditional ecological knowledge in marine conservation. Conserv Biol 19:1286-1293. https://doi.org/10.1111/j.15231739.2005.00158.x

Elliott G, Mitchell B, Wiltshire B, et al (2001) Community participation in marine protected area management Wakatobi National Park, Sulawesi, Indonesia. Coast Manag 29:295-316. https://doi.org/10.1080/0892075017504 75118

Heryanto MA, Supyandi D, Sukayat Y (2018) Agricultural Local Knowledge System: Lesson Learn from Rural Development in Mekarjaya Village, Kabupaten Purwakarta. IOP Conf Ser Earth Environ Sci 166:. https://doi.org/10.1088/17551315/166/1/012046

Hosen N, Nakamura H, Hamzah A (2020) Adaptation to climate change: Does traditional ecological knowledge hold the key? $\quad$ Sustain 12:1-18. https://doi.org/10.3390/su12020676

Johannes RE, Freeman MMR, Hamilton RJ (2008) Ignore fishers' knowledge and miss the boat. Fish Fish 1:257-271. https://doi.org/10.1111/j.14672979.2000.00019.x

Karki M, Hill R, Xue D, et al Knowing our Lands and Resources

Md Saleh MF (2014) Upholding Local Knowledge for Sustainable Fishery of the Unicorn Leatherjacket Filefish Aluterus monoceros: A Case in Malaysia. Fish People 38-43

Meilana L, Fang Q (2020) Local knowledge-based study on the status of horseshoe crabs along the Indonesian coast. Reg Stud Mar
Journal Homepage:

http://ejournal.undwi.ac.id/index.php/jsds
Copyright (C) 2021 Dwijendra University. All right reserved. 
Journal of Sustainable Development Science

Vol. 3, No. 2, December 2021, pp. 77-83

e-ISSN: 2715-9140|p-ISSN: 2722-919X

Sci 36:101252.

https://doi.org/10.1016/j.rsma.2020.1012 52

Rajamani L (2013) Using community knowledge in data-deficient regions: Conserving the Vulnerable dugong Dugong dugon in the Sulu Sea, Malaysia. Oryx 47:173-176. https://doi.org/10.1017/S003060531200 0154
Sintan M, Norjietta T, Rosliah K, Novi SKI (2019) Local wisdom in agriculture for environmental sustainability: A case study of the Dusun community. Int J Innov Creat Chang 6:117-138

Sintian M (2013) Kepercayaan Dan Amalan Masyarakat Kadazandusun Dalam Pemeliharaan Alam Sekitar. ND 1-12
Journal Homepage:

http://ejournal.undwi.ac.id/index.php/jsds
Copyright $\odot 2021$ Dwijendra University. All right reserved. 